\title{
Calcium and calcitonin responses to calcium infusion in type I diabetes mellitus
}

\author{
J.A. Amado, C. Gomez, S. Obaya ${ }^{1}$, M. Otero, J. Gonzalez-Macias \\ Endocrine Unit, Department of Internal Medicine and 'Department of Clinical Biochemistry, Valdecilla Hospital \\ School of Medicine, 39008 Santander, Spain.
}

\begin{abstract}
Summary: We studied calcium and calcitonin responses to intravenous calcium infusion $(3 \mathrm{mg}$ of elemental calcium/kg of body weight in 10 minutes) in 21 type I diabetic males and 17 age-matched normal males. Baseline total calcium, parathyroid hormone and calcitonin levels were normal in the diabetic group, but ionized calcium was lowered. Cortical bone status and osteocalcin levels were normal, suggesting a normal osteoblastic function. Total calcium and ionized calcium responses to calcium infusion were lowered in the diabetic group. Despite these lowered calcaemic responses, calcitonin secretion was normal.
\end{abstract}

\section{Introduction}

Several studies have shown a disturbed mineral metabolism and a decrease in bone mass in type I diabetic patients. ${ }^{1-4}$ The mechanisms underlying these abnormalities are not well known. Calcitonin deficiency has been proposed as a pathogenetic factor in involutional osteoporosis. ${ }^{5}$ In humans there are few and contradictory data on calcitonin secretion in diabetes. Schmitz et al. ${ }^{6}$ found a normal calcitonin response to calcium infusion in a group of ten patients with type I diabetes of short duration, while Witt et al.$^{4}$ found a higher calcitonin response to a calcium meal in a group of type I diabetic children. In this study we evaluated serum calcium and calcitonin responses to intravenous calcium infusion in a group of wellcharacterized type I diabetic males.

\section{Materials and methods}

The diabetic group consisted of 21 males aged $32.2 \pm 6.2$ years (range 21-41 years) with a duration of the disease of 92.2 \pm 64.6 months (range 24-256 months) and an insulin dose of $54 \pm 21.3 \mathrm{U} /$ day (range 16-80). All patients had a normal creatinine clearance and absence of significant proteinuria. Overt clinical

Correspondence: J.A. Amado, M.D.

Accepted: 1 December 1986 neuropathy was excluded in all of them. Their percentage of ideal body weight was $113 \pm 8 \%$. None of them had diabetic ketoacidosis defined as ketonuria and $\mathrm{pH}$ lower than 7.25 in the last year. The control group consisted of 17 matched for height and weight normal males aged $28.3 \pm 6.3$ years (range 24-43). Except for insulin in the diabetic group drug ingestion or diseases known to affect calcium metabolism were excluded in all individuals. The protocol of study was approved by the local investigation committee in accordance with the principles of the Declaration of Helsinki.

A ten minutes constant rate infusion of $3 \mathrm{mg}$ of elemental calcium (as calcium gluconogalactonate, Calcium Sandoz TM) per kg of body weight, in $100 \mathrm{ml}$ of isotonic saline, was begun at $0900 \mathrm{~h}$ after an overnight fast and before the morning insulin shot. Blood samples were obtained from the opposite arm at $-5,0,10,20$ and 60 minutes for total calcium, ionized calcium and calcitonin. At 0 time we also measured glucose, $\mathrm{HbA}_{1}$, phosphate, albumin, total proteins, creatinine, alkaline phosphatase, parathyroid hormone (PTH) and osteocalcin. Total calcium was determined using Corning 940 fluorometric titration (Corning Medical, Medfield MA). For ionized calcium measurement serum was obtained anaerobically and stored on ice until determined with a Space Stat ionized calcium analyzer (Orion Biomedical, Cambridge MA). ${ }^{7}$ Interassay coefficient of variation was $1.3 \%$ at a concentration of $1.1 \mathrm{mmol} / \mathrm{l}$. Glucose, 
phosphate, albumin, total proteins, alkaline phosphatase and creatinine were measured by Autoanalyzer (Technicon Corp., Terrytown NY). Total $\mathrm{HbA}_{1}$ was measured by chromatography (Isolab). Calcitonin, carboxyterminal PTH and osteocalcin were measured by direct RIA using kits furnished by Immunonuclear Corp., Stillwater MN. Intraassay and interassay coefficients of variation were respectively $5 \%$ and $14 \%$ for calcitonin, $4.5 \%$ and $13.3 \%$ for carboxyterminal PTH, and $6 \%$ and $8.6 \%$ for osteocalcin.

Cortical bone status was assessed as the ratio of cortical area (CA) to total area (TA) at the midpoint of the second metacarpal of the right hand. ${ }^{8}$

Results are given as mean \pm standard deviation. Statistical analysis. was done using Student's test or Mann-Whitney's U test when appropriate, and lineal correlation coefficient. Results were considered significant if $P<0.05$.

\section{Results}

Table I shows fasting blood and cortical bone status studies. No significant differences were found for any parameter, apart from glucose and $\mathrm{HbA}_{1}$. CA/TA was normal in the diabetic group.

Table II shows the responses to the calcium infusion. Baseline total calcium and calcitonin were normal in the diabetic group, but ionized calcium was significantly lower $(P<0.05)$. After calcium infusion total calcium and ionized calcium were lower in the diabetic group. Likewise maximal increase in total and ionized calcium (calcium at 10 minutes minus calcium at 0 minutes) was lower in the diabetic group. Calcitonin response in the diabetic group was normal. We found no significant correlation between baseline glucose or $\mathrm{HbA}_{1}$ and baseline or stimulated calcitonin. No correlation was found either between duration of the disease or CA/TA and calcitonin response.

\section{Discussion}

Calcium homeostasis seems to be abnormal in human diabetes mellitus, ${ }^{1-4}$ despite some negative reports. ${ }^{9}$ In this study we found normal levels of total calcium, phosphate, alkaline phosphatase, osteocalcin and PTH in a group of diabetic males, but ionized calcium was lowered, in accordance with a recent report by Fogh-Andersen et al. ${ }^{10} \mathrm{~A}$ low ionized calcium despite a normal total calcium may be due to increased calciumbinding properties of diabetic blood. Factors responsible for this are unknown. ${ }^{10}$ In spite of a lowered ionized calcium, carboxyterminal PTH was normal. This agrees with previous reports of normal to lowered PTH levels in diabetes. ${ }^{1,9-12}$ The lack of measurable response of the parathyroids to the lowered ionized calcium is unexplained though in this study we have not measured intact PTH, the most sensitive way of evaluating parathyroid gland function. Hypomagnesaemia, a frequent finding in diabetes, may be responsible. ${ }^{12}$ Regrettably in this study we did not measure magnesium levels.

Osteopaenia, as assessed by photon absorp tiometry, is found in diabetic patients of short durae tion (McNair et al. ${ }^{1}$ ) but in our group of patient cortical bone measured by CA/TA was normal. This could be due to the lower sensitivity of this method as compared to the other, or to the small number of patients studied.

Osteocalcin or bone Gla-protein is one of the most abundant proteins in the skeleton and it is synthesized

Table I Biochemical characterization of diabetic patients and control subjects

\begin{tabular}{|c|c|c|c|}
\hline & $\begin{array}{l}\text { Diabetic } \\
\text { patients }\end{array}$ & Controls & $\begin{array}{c}\text { Statistical } \\
\text { significance }\end{array}$ \\
\hline $\begin{array}{l}\text { Glucose }(\mathrm{mmol} / \mathrm{l}) \\
\text { HbA }_{1}(\%) \\
\text { Inorganic phosphate }(\mathrm{mmol} / \mathrm{l}) \\
\text { Total calcium }(\mathrm{mmol} / \mathrm{l}) \\
\text { Ionized calcium }(\mathrm{mmol} / \mathrm{l}) \\
\text { Albumin }(\mathrm{g} / \mathrm{l}) \\
\text { Total proteins }(\mathrm{g} / \mathrm{l}) \\
\gamma \text { glutamyl transpeptidase }(\mathrm{U} / \mathrm{l}) \\
\text { Alkaline phosphatase }(\mathrm{U} / \mathrm{l}) \\
\text { Creatinine }(\mu \mathrm{mol} / \mathrm{l}) \\
\text { PTH }(\mu \mathrm{g} / \mathrm{l}) \\
\text { Osteocalcin }(\mu \mathrm{g} / \mathrm{l}) \\
\text { CA/TA }\end{array}$ & $\begin{array}{r}9.8 \pm 5.5 \\
11.9 \pm 3.1 \\
1.20 \pm 0.26 \\
2.25 \pm 0.12 \\
1.17 \pm 0.02 \\
41.9 \pm 3.4 \\
65.6 \pm 3.5 \\
23.1 \pm 18.5 \\
79.6 \pm 21.4 \\
80.4 \pm 13.2 \\
0.48 \pm 0.20 \\
3.55 \pm 1.13 \\
0.8 \pm 0.09\end{array}$ & $\begin{array}{l}5.4 \pm 0.64 \\
8.44 \pm 1.32 \\
1.13 \pm 0.11 \\
2.17 \pm 0.09 \\
1.13 \pm 0.04 \\
43.2 \pm 3.5 \\
66.9 \pm 3.4 \\
21.2 \pm 11 \\
60.6 \pm 15.2 \\
86.6 \pm 13.2 \\
0.47 \pm 0.24 \\
3.79 \pm 1.43 \\
0.78 \pm 0.06\end{array}$ & $\begin{array}{c}P<0.01 \\
P<0.001 \\
\text { NS } \\
\text { NS } \\
P<0.05 \\
\text { NS } \\
\text { NS } \\
\text { NS } \\
0.05<P<0.1 \\
\text { NS } \\
\text { NS } \\
\text { NS } \\
\text { NS }\end{array}$ \\
\hline
\end{tabular}

NS = not significant . 
Table II Total and ionized calcium and calcitonin responses to calcium infusion in diabetic patients and control subjects

\begin{tabular}{|c|c|c|c|c|c|c|}
\hline - & -5 & 0 & $\begin{array}{c}\text { Time (minutes) } \\
10\end{array}$ & 20 & 60 & $\begin{array}{l}\text { Maximal } \\
\text { increase }\end{array}$ \\
\hline \multicolumn{7}{|l|}{ Total calcium (mmol/l) } \\
\hline Controls & $2.25 \pm 0.12$ & $2.19 \pm 0.080$ & $2.70 \pm 0.13$ & $2.52 \pm 0.10$ & $2.41 \pm 0.10$ & $0.52 \pm 0.12$ \\
\hline Diabetic patients & $2.17 \pm 0.09$ & $2.13 \pm 0.10$ & $2.54 \pm 0.13$ & $2.42 \pm 0.11$ & $2.32 \pm 0.10$ & $0.40 \pm 0.08$ \\
\hline Statistical significance & NS & NS & $<0.01$ & $<0.01$ & $<0.01$ & $<0.01$ \\
\hline \multicolumn{7}{|l|}{ Ionized calcium $(\mathrm{mmol} / \mathrm{l})$} \\
\hline Controls & $1.17 \pm 0.02$ & $1.16 \pm 0.05$ & $1.46 \pm 0.06$ & $1.34 \pm 0.03$ & $1.26 \pm 0.05$ & $0.30 \pm 0.06$ \\
\hline Diabetic patients & $1.13 \pm 0.04$ & $1.12 \pm 0.04$ & $1.36 \pm 0.05$ & $1.29 \pm 0.05$ & $1.23 \pm 0.05$ & $0.22 \pm 0.04$ \\
\hline Statistical significance & $<0.05$ & $<0.05$ & $<0.001$ & $<\overline{0.01}$ & NS & $<0.05$ \\
\hline \multicolumn{7}{|l|}{ Calcitonin (ng/l) } \\
\hline Controls & $50.3 \pm 14.3$ & $50.8 \pm 21.6$ & $95.5 \pm 43.5$ & $59.1 \pm 27.9$ & $54.4 \pm 19.6$ & $44.5 \pm 37.2$ \\
\hline Diabetic patients & $52.4 \pm 26.3$ & $53.4 \pm 27$ & $115.4 \pm 53.4$ & $81.1 \pm 32.3$ & $58.7 \pm 26.5$ & $64.9 \pm 61.5$ \\
\hline Statistical significance & NS & NS & NS & NS & NS & NS \\
\hline
\end{tabular}

NS = not significant

selectively by osteoblasts. A small fraction of newly synthesized protein is released directly into the blood, so serum osteocalcin levels reflect the amount of osteoblastic activity in the bone. ${ }^{13}$ Our finding of normal levels of serum osteocalcin suggests that osteoblastic function is normal in diabetes and that high levels of alkaline phosphatase found in some diabetic patients are of hepatic rather than bony origin. ${ }^{14}$

Total calcium and ionized calcium reached lower levels in diabetics than in normals after calcium infusion. Although the lowered baseline ionized calcium levels may have contributed to this finding, the maximal increase was significantly lower in diabetics, suggesting that there is a lowered calcaemic response in diabetes. This could be due to renal hypercal-

\section{References}

1. McNair, P., Madsbad, S., Christiansen, C., Faber, O.K., Transbol, I. \& Binder, C. Osteopenia in insulin treated diabetes mellitus. Its relation to age at onset, sex and duration of disease. Diabetologia 1978, 15: 87-90.

2. Levin, M.E., Boisseau, V.C. \& Avioli, L.V. Effects of diabetes mellitus on bone mass in juvenile and adult onset diabetes. $N$ Engl J Med 1976, 294: 241-245.

3. Raskin, P., Stevenson, M.R.M., Barilla, D.E. \& Pak, C.Y.C. The hypercalciuria of diabetes mellitus: its amelioration with insulin. Clin Endocrinol (Oxf) 1978, 9: 329-335.

4. Witt, M.F., Morimoto, S., White, N.H., Santiago, J.V. \& Avioli, L.V. (1983). Defective cortical bone remodeling in insulin dependent diabetes mellitus. Abstract. Calcif Tissue Int 1983, 35: 678.

5. Taggart, H. McA., Chestnut III, C.H., Ivey, J.L., ciuria. ${ }^{3,11}$ Baseline calcitonin levels were normal in accordance with other studies. ${ }^{6,9}$ Despite the lowered calcaemic response, calcitonin levels increased normally, as previously reported in a smaller group of recently diagnosed patients. ${ }^{6}$ The degree of metabolic control as measured by glucose and $\mathbf{H b A}_{1}$, or duration of the disease did not influence calcitonin response. In this group of type I diabetic patients calcitonin secretion was normal.

\section{Acknowledgements}

The authors express their gratitude to Ms Blanca Paule, Ms Concepción Rentería and Ms Isabel Villa for their technical assistance.
Baylink, D.J., Sinson, K., Huber, M.B. \& Roos, B.A. Deficient calcitonin response to calcium stimulation in postmenopausal osteoporosis? Lancet 1982, i: 475-477.

6. Schmitz, D., Christiansen, C.K., Christensen, S.E. \& Emmertsen, K. Basal and calcium stimulated serum calcitonin in insulin-dependent diabetics. Horm Metab Res 1984, 16: 100-101.

7. Larsson, L. \& Ohman, S. Effect of silicone-separator tube and storage time on ionized calcium in serum. Clin Chem 1985, 31: 169-170.

8. Nordin, B.E.C. Osteoporosis with particular reference to the menopause. In Avioli, L.V. (ed) The Osteoporotic Syndrome. Grune \& Stratton, New York, 1983, p. 1343.

9. Heath, III, H., Lambert, P.W., Service, F.J. \& Arnaud, S.A. Calcium homeostasis in diabetes mellitus. $J$ Clin 
Endocrinol Metab 1979, 49: 462-466.

10. Fogh-Andersen, N., McNair, P., Moller-Petersen, J. \& Madsbad, S. Lowered serum ionized calcium in insulin treated diabetic subjects. Scand J Clin Lab Invest 1983, 43 (suppl 165): 93-97.

11. Witt, M.F., White, N.H., Santiago, J.V., Seino, Y. \& Avioli, L.V. Use of oral calcium loading to characterize the hypercalciuria of young insulin-dependent diabetics. J Clin Endocrinol Metab 1983, 57: 94-100.

12. McNair, P., Christensen, M.S., Madsbad, S., Christian- sen, C. \& Transbol, I. Hypoparathyroidism in diabetes mellitus. Acta Endocrinol 1981, 96: 81-86.

13. Price, P.A., Williamson, M.K. \& Lothringer, J.W. Origin of the vitamin $\mathrm{K}$-dependent bone protein found in $\subseteq$ plasma and its clearance by kidney and bone. $J$ Biol Chem 1981 256, 12760-12766.

14. Goldberg, D.M., Martin, J.V.\& Knight, A.H. Elevation of serum alkaline phosphatase activity and related enzymes in diabetes mellitus. Clin Biochem 1977, 10: 8 11. 